DE DE GRUYTER

OPEN

$G$

DOI: 10.2478/topling-2014-0004

\title{
From Modernity to Post-Modernity: Conflicting Voices in Literary Discourse - A Corpus Analysis of You and One
}

\author{
Alcina Maria Pereira de Sousa \\ University of Madeira, Portugal \\ Alda Maria Correia \\ New University, Portugal
}

\begin{abstract}
This paper discusses the possibilities of a corpus analysis applied to literary study and interpretation. It is thus its goal to present some findings related to the disambiguation of some pronominal references, i.e. you and one, as they occur in speech and thought presentation in prose fiction, across periods in the 20th century. The texts selected are two of Virginia Woolf's novels (early and late modernist period) and one by Hugo Hamilton (in the postmodern era). The analysis benefits from a multi-layered interpretive framework drawing on discourse analysis, corpus-based approaches and literary study, particularly in that it unpacks ways in which writers make use of linguistic structures. These involve readers in a dialogic interpretation of the text's "polyphony" and "heteroglossia", either conveying the generic pronoun reference or the protagonist's inner voice.
\end{abstract}

Keywords

Self-consciousness, pronoun reference, prose fiction, modernism, postmodernism.

Introduction and aims

From modernity to postmodern discourse, places, landscapes and people have been aesthetically perceived and reshaped within the perspective of alterity/otherness, upon which one constructs the image of "one's own" and the "other" in a dialogical game of mirrors. Following Stanzel's long-established stance, this paper pursues an interest in interweaving language analysis of fictional texts, particularly relevant in the case of encoding personal experiences and conveying internal perspectives in narratives belonging to different periods of the 20th century, using techniques borrowed from corpus linguistics. In fact, writers resort to a wide panoply of language resources to represent characters' speech and thought, yet it seems relevant to shed further light on striking features as well as patterns of variability stemming from patterns of language use. These have been the focus of interest of diverse disciplinary frameworks across time (cf. Mclntyre, et al., 2004). It is worth mentioning the studies of written fiction from a stylistics standpoint by Leech and Short (1981), Hutcheon (1984), Fludernik (1993), and Semino, Short and Culpeper (1997). In the aftermath of the broad 'Lancaster Speech, Writing and Thought Presentation Written Corpus' project, having investigated not only written narrative texts (prose fiction, newspaper news reports and [auto]biography) but also literary texts (Leech and Short, 1981), Martinez (2008) and Asaka (2008; 2010) presented some corpus research on speech and thought presentation solely drawing on modernist texts.

In so doing, the focus of the analysis of pronominal references you and one has broadened the scope of the corpus selection contrasting two periods as well as resorting 
to a corpus-based analysis of a quantitative kind. This study addresses two questions:

- Are shifting focalisations linguistically manifested in the corpus under scrutiny?

- Is there a cline in pronominal reference (you and one) in prose fiction, from modernity to postmodernity?

This is also intended to shed some light on the narrator's report of voice and the narration of internal states as they occur in prose fiction, namely in two novels by Virginia Woolf and one by Hugo Hamilton. The analysis of their contexts of occurrence / patterns of collocation, from the sentence to the textual levels (Biber, et al., 1998; Sinclair, 2004), is meant to show the way one and you involve readers in a dialogic interpretation of the text's "polyphony" (Bakhtin, [1930] 1981), either conveying the generic pronoun reference or the protagonist's inner voice. The current analysis benefits from a multi-layered interpretive framework drawing on discourse analysis, corpus-based approaches and literary study and interpretation, particularly in that it unpacks ways in which writers resort to linguistic structures in use.

\section{Background}

Studies on categories of speech and thought presentation have been carried out in the scope of stylistics and related fields for over two decades. Leech and Short (1981) focused on the narrator's report of voice and the narration of internal states. The latter have been offered less attention than other forms of thought presentation and in inward details are believed in Toolan's contention to be "matters of which the character is not consciously aware" (Toolan 2001, p. 119, cited in Semino and Short, 2004, p. 47). Back in 1997, Semino, Short and Culpeper argued that "the speech and thought presentation scale is a cline rather than a series of discrete categories. It also suggests that some category boundaries (especially those at the direct/free indirect boundary) are less clinal than others" (Semino, Short and Culpeper, 1997, p. 1). Hutcheon has also discussed auto-referentiality on the level of narrative and emphasised that the "most effective method of analysing the extended thematization of linguistic identity is by the detailed study of one particular text which can then act as a model both of the form (and techniques employed) and of its implications for the theory of fiction and for the act of reading" (Hutcheon, 1984, p. 104). As for the discussion of a cline in modernist fiction, it is worth mentioning Sotirova's case study (2009, p. 49) on Joyce's use of pronouns to refer to characters in free indirect style, seemingly building "discourse inconsistencies (often interpreted with regard to the disintegration of the modernist self), rather than allowing readers to interpret pronominal references automatically". In her bearings "the best way to account for this bizarre strategy is by aligning it to spoken discourse where vague pronominal references, in the form of personal pronouns and demonstrative pronouns, are commonly found". She reiterates previous discourse analysts' views that "the construction and understanding of reference is a joint endeavour of speaker and addressee".

Supported by a corpus stylistics approach (cf. Wynne, Short and Semino 1998; Semino and Short, 2004; Wynne, 2006; Mahlberg, 2007) Asaka analysed, at first (2008), the narrative form and the occurrence and collocational patterns of the personal pronoun one in one of Woolf's consciousness-describing narrative, i.e., To the Lighthouse (Woolf, 1927). The analysis provides evidence that one is used as a "compromise pronoun", as advanced by Daiches (1942, p. 64), in that it may be employed either in third-person narrative or in first-person narrative. In Asaka's contention (2008), using one in this way alters the perceptions readers have of characters' consciousness in a smooth way, making the narrator's presence less visible, particularly when there are no quotation marks; yet the linguistic analysis of the collocational meaning should intertwine with the sentence, text and discourse levels as well as narrative forms. Asaka further claims, drawing on the analysis of three of Woolf's short stories (2010, p. 13), that we, you and they give an objective point of view, I gives a subjective point of view and one gives neither, creating alternatively ambiguity and an unclear image; the use of one is therefore central in the construction of the stream of consciousness technique. Asaka (2008) also points out that the frequent occurrence of one in various narrative forms in To the Lighthouse is mostly evidenced in the thoughts of Mrs. Ramsay and Lily Briscoe.

By contrast, in a previous study on Hamilton's Speckled People, Sousa (2008) singles out the occurrence of the personal 
pronoun you conveying shifting points of view at the level of the literary discourse which involve the reader in a dialogic interpretation of the text's "heteroglossia". The novel takes the form of an autobiographic journey by Johannes (Hugo) Hamilton, its narrator and protagonist, through fictive and imaginary settings in a quest for identity. In the process, the actual reader has the chance to interact with the focaliser's own thoughts (cf. Genette, 1988) and efforts to make sense of the other's registers.

Bearing in mind that enacting the "self" as a linguistic act also presupposes that the narratives and their language (Hutcheon, 1984 , p. 114) "are not estranged from the readers' reality", it is worth analysing whether (1) shifting focalisations are linguistically manifested in the corpus under scrutiny by focusing on the use of pronouns one and you to refer to narrators' and characters' voice and internal perspective, and (2) whether there is a cline in pronominal reference (one and you) in prose fiction, from modernity to postmodernity, also reflecting language use and change in English. Indeed, and following Widdowson ( [1975] 1991, p. 33), "an interpretation of a literary work as a piece of discourse involves correlating the meaning of a linguistic item as an element in the language code with the meaning it takes on in the context in which it occurs. This correlation procedure is necessary for the production and reception of any discourse, [...] the basis for the understanding of literature in particular."

If on the one hand, literariness requires from the reader a focus on figures of speech, tropes and their meaning in context, as well as aspects of texts/genres, it also embraces other dimensions of linguistic analysis from re-registration, semantic density, polysemy, pragmatics of coherence, to name some of the layers pointed out by Carter (1997). The current study will draw on a corpus-driven approach for a more systematic analysis of linguistic choices at the level of discourse (Baker, 2006; 2010).

\section{Selecting the corpus}

Given the scope of this study, the corpus involves a limited number of texts selected, with a total of 159437 words (Night and Day, 170140 words; Between the Acts, 46 929 words; The Speckled People, 95468 words). By departing from a limited corpus selection (and without overlooking issues of representativity indebted to corpus selection), this study is intended to uncover a fresh and more systematic insight into the texts' meanings than have been discussed in the literary critical literature. Following Semino and Short's data discussion on thought and presentation, evidenced in the corpus selected across genres, the (auto)biography section has the largest number of instances, and they conclude that (2004, p. 137) "both (contemporary) fiction and (auto)biography are often greatly concerned with the thoughts and internal states of characters/participants, and therefore have similar amounts of thought presentation [...] of inferred thought presentation".

Both Woolf's and Hamilton's texts seem of interest because a first reading of the texts points to the use of distinctive overt techniques of linguistic self-consciousness. In the novels Night and Day [ND] (1919), and Between the Acts [BA] (1941) by Woolf, belonging to the early and late modernist stage of her writing, respectively', the reader is led to acknowledge the occurrence of a seemingly distinct pronoun reference from other narratives in the postmodernist period, namely the one by Hamilton in The Speckled People: A Memoir of a Half-Irish Childhood [SP] (2003). On the one hand, Woolf is acknowledged for her deep concern with the rendering of states of consciousness as well as the quest for an innovative and creative writing, throwing her into the realms of some of the postmodern writing conventions. On the other, Hamilton's autobiographical narrative presents the protagonist's efforts to make sense of the world, at times from a child's perspective, at other times from an adult narrator's stance, which is conveyed at the level of the narrative discourse in a sort of experimental writing.

\section{Conceptual framework}

The tools developed within the framework of corpus linguistics provide a convenient construct for studying, among other subjects, how a writer uses certain words

1 Nasu (2010) has reiterated former claims on Woolf's considerable shifts in mode of writing. After To the Lighthouse (1927) "her works can be divided into two groups in terms of style of writing employed to represent human consciousness" (Nasu, 2010, p. 1). 
and phrases, whether there are specific patterns in his/her use of language, and what issues these patterns may identify. This kind of research can make a substantial contribution to bringing together corpus data, linguistic analysis and stylistic interpretation. Prior to a brief account of the pronoun references one and you and their importance in disclosing modes of narration and representation of speech, it is noteworthy to refer to its stylistic concern for disclosing voice, as is defined by Wales in her Dictionary of Stylistics: "to describe 'one who speaks' in a narrative, whether the IMPLIED AUTHOR, or CHARACTER, or both (as in free indirect speech)" (Wales, 1989, p. 478; author's emphasis). Semino, Short and Culpeper (1997) give an account of the narrator's report of voice and the narration of internal states within a corpus-driven approach. As such, this study may address a wide range of fundamental questions concerning the nature of linguistic and literary originality and creativity, and how corpus data can be used (or misused) in assessing a particular author or text in this regard.

Before presenting some illustrations from the corpus, it is worth referring to linguistic and discursive choices of the standard pronominal references in English as presented in prescriptive and descriptive grammars and dictionary sources $(A$ University Grammar by Quirk and Greenbaum, 1993; Collins Cobuild Grammar, 1992; Cambridge Grammar of Spoken and Written English and Usage by Carter and McCarthy, 2006; The New Shorter Oxford English Dictionary, 1993, in this order) or even Google.

In English, one can have different morphosyntactic forms, i.e. a cardinal (numeral), or used as an adjective and determiner, and even as a partitive, a proform and a personal pronoun reference. In this case it is the third-person singular, referred to as "subjective" in subject position and "objective" in object position (dative and accusative) (cf. The New Shorter Oxford English Dictionary, 1993; 1997). It is this pattern of use as a pronoun which is of interest for the current study in that it points to "any person of undefined identity, as representing people in general" (NSOED, $1993 ;$ 1998). The sort of collocations provided in the dictionary entry was retrieved from literary texts by Wilde and Rhys, for example, and technical/professional discourse.
You is also a pronoun reference, yet accounting for the second person or the generic reference. There is a marked distinction in the use (register and period) of both forms, in that one points to a degree of formality inherent to scientific and technical discourse; you is related to contemporary use in several discourse communities and discursive practices. A quick search on the Google search engine provides 15420000 000 entries for the entry you and 8810000 000 entries for the item one. Hence, you occurs more frequently in 100 examples of '[word="you"] cut 100' (in the British National Corpus)

In 2010 , Asaka stated $(2010$, p. 3) that:

First, one is considered as a generic pronoun which indicates 'anybody'. Then if those pronouns we, you, they, people and one are all generic pronouns referring to just 'a generic person', it might be possible to replace one with other generic pronouns. However, these pronouns possess different functions when used as generic pronouns. Jespersen $(1961: 4.71,4.73)$ says that we includes the speaker himself even in generic use, you also suggests the presence of the hearer or reader, and they is equal to people, it suggests the exclusion of the speaker and addressee.

Biber, et al. (2002, 4.12.2) also include we, you and they as generic pronouns and suggest that "these generic pronouns tend to retain a trace of their basic meaning as first-, second-, or third-person pronoun". These explanations imply that we, you and they possess a more firm "figure" than one. The word "figure" represents "the embodiment of physical presence" (Nasu, 2002 , p. 63), which is interpreted as the "actuality" or the "entity" that most personal pronouns provide behind the words. Even in generic use, we suggests the image of the speaker, you the addressee, and they people who are not the speaker nor the addressee. One is sometimes regarded as an equivalent of $I$ representing the speaker. Since the narrator in Night and Day, for instance, employs $I$ and one, it may be possible to see these pronouns as the same. However, for the same reason with the other personal pronouns above, $I$ and one cannot be taken as being exactly the same. The pronoun $I$ possesses a more stable "figure" than the pronoun one of undefined kind.

\section{Method}

Concerning the crisscrossing of corpusbased approaches with other domains of 
linguistic scrutiny (Biber, et al., 1998; Sinclair, 2004; Partington, 1998; Hoey, 1991; 2001; 2005; Sampson and McCarthy, 2004; Baker, 2006), namely discourse analysis and corpus stylistics, it might be stated that much research now heavily departs from data encoded in computational resources. The texts selected (Night and Day and Between the Acts by Woolf, and The Speckled People by Hamilton) were retrieved in digital format and saved in RTF.

For (Macleod, 2005, p. 61) "an objective and verifiable description of the relevant linguistic features of a text", notably the analysis of frequencies of the nodes you and one in the corpus of texts selected, this study resorted to the use of a concordancer, ConcApp Concordance 2 , and Word Profiler Version 4 for Windows (98, ME, NT / 2000, $X P)$. Corpus tools allow for the electronic retrieval of, for instance, pronouns (words) in concordance lines/strings ${ }^{3}$, displaying their context of occurrence (phrases). The term context, as perceived in corpus linguistics, plays an important role by involving the analysis of, to borrow from Biber, Sinclair and Partington (also cited by Hoey, 2005 , p. 163), "collocations, semantic associations, colligations and textual collocations".

Firstly, the study entailed manual search techniques towards pronoun reference identification in the corpus: one and you, followed by a comparison of the frequency ${ }^{4}$ of occurrence of both items in the corpora under scope. Thirdly, it comprised an analysis of the co-text of the pronoun references, given that "the frequent absence of reporting clauses in free indirect speech means that readers have to infer the identity

${ }^{2}$ Concapp downloaded at 11.09.05 - 19:00, at http://www.edict.com.hk/PUB/concapp/.

3 "A concordance is simply a list of all of the occurrences of a particular search term in a corpus, presented within the context that they occur in, usually a few words to the left and right of the search term" (Baker, 2006:

71) and "concordance analysis is one of the most effective techniques which allows researchers to carry out this sort of close examination."

4 "Frequency is one of the most central concepts underpinning the analysis of corpora. It is important to understand that frequency lists are a good starting point and used sensitively they can illuminate a variety of interesting phenomena." (Baker, 2006, p. 47). of the relevant speaker from contextual clues, and so there may in some cases be an ambiguity as to whether a particular stretch is narration or FIS (Semino and Short, 2004, p. 83). Then, it involved the analysis of the type of collocates (Halliday, 1994, pp. 106-175) and semantic prosody (co-text and context), thereby discarding from the number of occurrences:

(1) one - indefinite and compounds (one of, any/no one ), numeral/cardinal, proform

(2) you - in direct speech (characters' taking turns)

The final stage of the analysis comprises triangulation (Baker, 2006, p. 16), thereby facilitating validity checks of research questions.

\section{Results and discussion}

So as to address the first research question, namely the sort of linguistic and discursive choices evidenced in the texts selected of a cross-period nature this study focused first on the analysis of the occurrences of the pronouns one and you. A query on their occurrence in the British National Corpus discloses an overriding number of instances related to you ( $n=$ compared to the occurrence of one (2.27/0.44) across genres and discourse communities at present.

On the whole, the personal pronoun you in the corpus selected (cf. Table 1) occurs more frequently in Night and Day (1616 instances) as the narrator renders more frequently characters' words in direct speech. Yet, for the narrator's report of voice and the narration of internal states, the study entailed the analysis of strings and cotext to single out the occurrences of one and you. In this case, The Speckled People evidences a larger number of occurrences of you $(=502$ instances out of 668 occurrences / $0.72 \%$ ) than the texts by Woolf, from the modernist period. By contrast, one occurs more frequently $(=223$ instances out of 784 occurrences / $0.47 \%$ ). Still, the role of one in each narrative text by Woolf differs, and it is possible to examine the effects by looking at sentences from each text.

\footnotetext{
5 "Semantic prosody", borrowing from Sinclair $(1987 ; 1991)$, accounts for the phenomenon in which an item with association with others, its collocates, as offered in a concordance sample, acquires a "favorable or unfavorable connotation" (Partington, 1998, p. 66).
} 
Table 1: Occurrences of one and you in ND, BA and SP

\begin{tabular}{|c|c|c|c|}
\hline $\begin{array}{c}\text { Lemma /Total } \\
\text { Words }\end{array}$ & $\begin{array}{c}\text { Night and Day } \\
46 \text { 926 Total } \\
\text { words } \\
11002 \text { unique } \\
\text { words }\end{array}$ & $\begin{array}{c}\text { Between the Acts } \\
170140 \text { Total words } \\
6658 \text { Unique words }\end{array}$ & $\begin{array}{c}\text { The Speckled People } \\
265324 \text { Total words } \\
13296 \text { Unique words }\end{array}$ \\
\hline you & $\begin{array}{c}0 \text { (out of } n=1616 \\
/ 0.95 \%)\end{array}$ & 2 (out of $n=225 / 0.46 \%)$ & 502 (out of $n=668 / 0.72 \%)$ \\
\hline one & $\begin{array}{c}223 \text { (out of } n=784 \\
/ 0.47 \%)\end{array}$ & 26 (out of $n=152 /=.32 \%)$ & (out of $n=403 / 0.42 \%)$ \\
\hline
\end{tabular}

In Night and Day (1919), the pronoun reference you occurs more frequently $(n=1$ $616)$ in instances related to the dialogue form, rendering characters' words in direct speech, i.e.., form of address (pronominal reference in direct speech either in subject or object position); or as a collective (i.e. "you and I"; "you and me", "you all"). There are 223 instances of one occurring either as a generic (cf. strings 5,6 ) and an inner voice (cf. strings 8,6 ). Hence, In strings 3 and 4 , for example, one underpins the formal register denoting a linguistic choice much in use at the period.

3. anged her. Naturally," he added, "

4. ntly upon the pane, "that for all

5. th his conception of life that all

6. ant one still is, in spite of all

7. r," Katharine repeated. After all,

8. herself. That wouldn't do at all.

9. ed in an attitude that was almost

In Night and Day the narrator is 'theoretically' an omniscient one, whose seemingly distant and impersonal point of view, avoiding narratorial remarks, is supported by the use of one, to show especially Katharine's doubts and hesitations, which are dislocated to an unknown and uncertain group of people. This point of view moves beyond the limitations of other individual characters, creating a narrative consciousness which identifies with different perspectives. The use of one enables the construction of this structure, leading us to the first modernist experimental techniques developed by Woolf. Katharine's strong desire to transform or escape from her given world and her simultaneous composure, control and inability to make radical decisions explains another aspect of the use of the pronoun one. By using this form in impersonal contexts like "but she still looked more like one who reasons than one who feels", "one doesn't know any more, does one?" Katharine's doubts and hesitations are dislocated from her to an unknown and uncertain group of people who may or may not exist in the plot, may or may not share her beliefs.

In Between the Acts (1941), the pronoun reference you $(=225)$ is used in turn-takings, as a form of address, underpinning phatic communion, as follows:

(1) pronominal reference in direct speech either in subject or object position:

1. ke it. "Mrs. Manresa, I'm going to ask you a favour--If it comes to a pinch this af

2. dear old Mr. Carfax. . Can't we give you a lift, if you don't mind playing bodkin

3. down came the rain. But I wanted to ask you, about the new clergyman, the one who's

10. as words could say it. "I don't admire you," and looked, not at his face, but at hi

11. "that there ever were such people. Only you and me and William dressed differently."

12. innocent. Think, I implore you, before you answer. ELEANOR. . . I have thought--

13. rvants. I'm nothing like so grown up as you are." She preened, approving her adoles

14. aken. . . But it occurred to me to ask you, as a friend of the family, in confidenc

15. e chits you dally with, and bid me meet you at the orange Tree when you're drowsing

16. arried with him. "You wild beast. . . you bad beast," he grumbled, stooping. Georg

17. so fair, so innocent. Think, I implore you, before you answer. ELEANOR. . . . I ha

18. $n$ the papers--the case about the dog? D'you believe dogs can't have puppies? . . A 
(2) collective (i.e. "you and I"; "you and me", "none of you"):
4. dle. Gentles and simples, I address you all (she pif
5. ped:
Gentles and simples, I address you all. .
7. th Flavinda. Sir Smirking Peace-be-with-you-all, a clergyman. Lord and Lady Fribble.
8. loser. Let me whisper in your ear. . . You and I have long entertained a high opini
9. eople. There was a time, Sir John, when you and I were always first on top. Now . .
11. "that there ever were such people. Only you and me and William dressed differently."
220. Manresa laughed. "You wouldn't. None of you would. You see I'm on a level with...
210. Pharaohs. Dentists. Fish... Oh yes, you were saying, Isa, you'd ordered fish; an
211. ar barrel! (Aloud) Your meaning, Madam? You were saying? LADY H. H. I have a niece,

(3) Informal register "ye"

1. child Flavinda; with this proviso, mark ye. That she marry to her Aunt's liking. He

2. g. Her Aunt; that's me. Otherwise, mark ye, all--to wit ten bushels of diamonds; it

3. ifles needless to specify he left, mark ye, should she fail to marry to her Aunt's

4. cried "Quick Deb, the blue bag." I told ye... La, to think I read it all in a bo

In Between the Acts, there are but two instances related to the use of the pronoun you as a generic stance:

3. one of the great trees laid flat. There you could walk up and down, up and down, und

49. rash. Mrs. Ball's cottage was not what you might call clean. In the last war Mrs.

On the contrary, there are 26 instances in which one (out of 152 occurrences) is used as a generic (cf. strings 66 and 67 ), at times, other times conveying an inner voice (cf. strings 68 and 69):

66. brother. "My brother," she added "says one mustn't thank the author, Miss La Trobe.

67. h her head on one side, she listened. "one never knows," she murmured, "if there's

68. Peace, let her pass. She to whom all's one now, summer or winter. Peace was the th

69. d out) I mind me that, I to whom all's one now, summer or winter. You say the sun

One also conveys formal register, thus marking a stylistic choice of the narrative text of the modern period:

94. rocade was visible half-way up; and, as one reached the top, a small powdered face,

The narrator's presence is in constant change, not heard when characters are quoted but noticeable when a character is described or when he blends characters' thoughts; there is the juxtaposition of scenes and images, broken syntax, suspended thoughts, cries, sounds of natures, ellipsis, mixture of discourses, leading to infrequent/unspecific use of you/one, representing speech and thought, by means of shifting focalisations:

123. roplanes, I didn't like to say it, made one think. . . . No, I thought it much too s

99. r voice speaking, the voice that was no one's voice. And the voice that wept for hum

or the inquisitive mind, via rhetorical questions:

92. house. Yet somehow they felt-how could one put it-a little not quite here or there

The reader's attention is drawn to the activity of the words, obstructing the referential function of language, i.e. a conflict between world and words, as may be inferred from the following string:

97. g well over an hour. And you know, when one's a child, how long that seems." "Marri

The dialogical game of mirrors mentioned in the introduction is obtained with real mirrors, introduced in the final and chaotic part of the play ("the mirror bearers squatted; malicious; observant; expectant; expository" $B A, \quad$ p. 99), when the representation merges with the real audience in a mixture of unidentified characters to whom Reverend Streatfield 
(one of the characters in the audience) addresses, puzzled and confused:

"We were not given to understand - am I too presumptuous? [...] To me at least it was indicated that we are members, one of another. Each is part of the whole. Yes, that occurred to me sitting among you in the audience. [...] That I leave to you."

[...] Friends hailed each other in passing.

"I do think," someone was saying, Miss Whatshername should have come forward and not left it to the rector [...] O my dear, I thought I utter bosh. Did you understand the meaning?

(BA, pp. 103; 105).

The pronominal references are used in fragments ("Scraps, orts and fragments" $B A$, p. 103), dispersed ("Dispersed are we, the gramophone repeated" - $B A$, pp. 52, 53, $105)$, unrelated to a specific situation in a kind of dissolution of perspective of the narrative consciousness. Woolf uses them as part of the dramatisation of the conflict of postmodernist aesthetics; Miss La Trobe, the artist, is the creative figure presenting her disconnected pageant, but her absence in the end leaves only randomness, incomprehension and exasperation in the audience and the reader.

Finally, when considering The Speckled People (2003), Hamilton's use of you is rather distinctive and occurs more frequently in the text $(n=668 / 0.72 \%)$ than the node one (403 instances). Yet, the corpus analysis of the morpho-syntactic feature of one pointed to its use solely as an indefinite, accounting for number or as a partitive. As might be expected, the use of pronominal reference you $(n=166)$ occurs when characters address each other in direct speech stances (Genette, 1988). It is a deictic marker in characters' turn-taking, either in subject or object position, evidenced in the following strings:

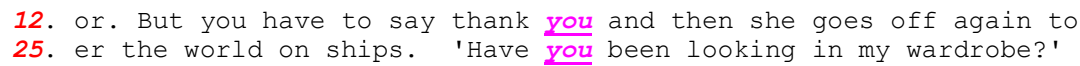

Yet, there are two differing uses of you $(n=502)$ when compared to Woolf's selected texts: the self-referring you and the generic you. The generic you can be replaced by one and expresses common knowledge or a shared opinion, highlighted in the following lines:

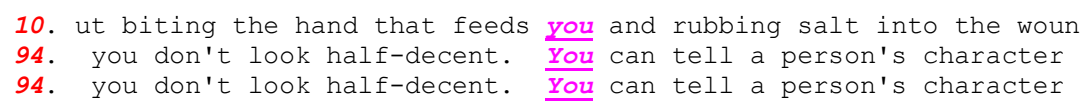

In very many instances retrieved from Hamilton's narrative, you is also used in reported statements, in which there are shifting focalisations, from the child-narrator to the adult-narrator as well as the characters' own focalisations:

$$
\text { 5. s you can only be innocent if you admit the guilt. You can only }
$$

Indeed, the speaker, using a universallyreferring feature (Trengove, 1975, p.53-55), seems to hedge commitment, being unidentified, which emphasises the generic nature of the pronoun reference as a "homogeneous body of opinion" (Trengove, 1975 , p.49), presupposing that it should be taken as truth-value. It appears to account for the general opinion shared either by the all-Irish community, fiercely defended by the protagonist's father, or the local community in which he lived, likely to be inferred from the following excerpt (SP, p. 166):
If you wanted to have friends you had to start speaking to yourself in English, so that nobody would call you a mahogany gas pipe or a sad fucking sap or think that you were from Connemara long ago [Italics ours].

The self-referring you conveys emotions, states of mind and flights of imagination. It reflects the protagonist's particular experience of the community and struggle to live (in)between identities and countries (Bhabha, 1998), evidenced in the following strings $(S P)$ : 
The examples inserted so far suggest shifts from the generic reference to the expression of a personal resolution, and in some cases, pinpointed by a confiding tone about decentred positions and affiliations in the diegetic world:

That's why it's important to work hard and invent lots of new things in Ireland and fight for small languages that are dying out. Because your language is your home and your language is your country. What if all the small languages disappear and the whole world is speaking only one language? We'll all be like the Munster poets, he says, lost and blind with nothing to welcome them only doors banging in the wind (SP, p. 161).

\section{Data discussion}

The data presentation and synthesis previously displayed allows for a brief discussion not only on the way writers/speakers exploit language variation to communicate their intended messages but also on the sort of contribution that linguistic forms or stylistic variation have on readers' interaction with the text and its language for meaningful interpretation. In the process, a broader understanding of the world, and not only of the diachronic dimension of language underpinning reading development, should support any reader's behaviour.

Concerning the first research question, whether shifting focalisations are linguistically manifested in the corpus under scrutiny, it is possible to advance that Woolf uses the language process of differentiation to dramatise intentionality and consciousness in her novels through consecutive transitions between different frames that establish multiple levels and meanings between the public and the private. This "phenomenology of perception and expression" (Harper, 1982, p. 5), which involves the question of the narrative voice and modes of narration, is developed and develops along her novels through the use of direct speech, indirect speech, free indirect speech, interior monologue or soliloquy. "One" occurs more frequently in Woolf's corpus. This evidences a linguistic/stylistic choice conforming to patterns of use from modernity to postmodernity which draw attention to her way of conceiving her feminist project and a postmodern aesthetics. In Between the Acts, intended to be a "series of contrasts" (Woolf, 2002 , p. 159), she uses all types of techniques and a fluctuating point of view to explore the problems of communication and the dissolution of perspective.

Bearing in mind the exploratory analysis of the corpus under scrutiny there is a distinctive trend in pronominal reference reflecting the language in use (BNC): One modern period; you - postmodern period. As for the the pronominal references one and you, as evidenced in Night and Day, Between the Acts to The Speckled People, they seemingly point to:

(1) fragments, unrelated to a specific situation in a kind of dissolution of perspective of the narrative consciousness, most strikingly occurring in Woolf's texts $(B A)$;

(2) a multitude of pulls either inwards or outwards, be it in the sphere of the individual and the community to which the protagonist belongs, or in the physical space in Hugo's text, by "focusing on the lack of a single unified self-concept" (Lakoff, 1996: 117). Very often in the novel, the focaliser/protagonist presents an alternative view to mainstream ideology, reinforced by the generic pronoun reference you.

Hugo's subjectivity evolves from boyhood up to adulthood, punctuated by uncertainties, anxieties, insecurities on the cutting edge of a new era at which the local, the national, and the global have disrupted (Lakoff, 1996, p. 117) "the Cartesian dualist tradition" by "focusing on the lack of a single unified selfconcept". This might be singled out in the multiple identities conveyed, for instance, by the personal reference $I$ - me - myself opposing he - him - himself, or even you yourself (sometimes generic, or expressing a personal resolution in a confiding tone). You might be disambiguated as "the outside community", "our family", on the one hand, and on the other, (Belsey, 2002, p.59) "the decentring of the subject" to be illustrated in the shifting perspectives I / you [Irish speakers] as they are often disambiguated further on in the context of occurrence and referring predominantly to Ireland ${ }^{6}$.

6 These words occur several times in the corpus, notably Ireland (199 instances), Irish (345 instances), British (66 instances), British (66 instances), England (94 instances), English (94 instances), Germany (147 instances) and German (167 instances), among others. The analysis of the occurrence of these lexical items and other spatial anchors within the same lexicosemantic field, such as soil, ground, land, country, place, and sea, also an example of 
In a wider frame, other questions could be discussed: how different is the construction of identity stability in Woolf's and Hugo's characters, considering the authors' control of their native language? Woolf speaks an elite British English and masters all its specificities. Hugo was forbidden to speak English. Another question is the genre of the texts under analysis: Woolf tried to build a new literary proposal, the novel of the future, which she called "play-poem". Hugo writes a childhood memoir in which literariness is not the first aim and in which identity and language are approached from a child's limited and reductive point of view.

The scrutiny of pronominal references within a discourse-based view, drawing on corpus research, has come to unveil another level of response to language use at the level of literary discourse. Hence, this interdisciplinary approach to language research suggests tools guiding readers to create meaning out of words and is meant to lead readers into the pulls of texts (binaries) and their polyvocality. After all, posits Stockwell (2002, p. 79): "The reader has to keep track of all these different voices and relations between them, both along the deictic field dimensions and into the different levels. This then is the architexture to the texture".

Moreover, old/new periods might be well depicted towards a more cross-period, multilingual and multicultural canon with a focus given on cohesion, register and discourse so as to show that, and using Simpson's words on critical reading (1997, pp. 4-5), "finding out about what writers do is a good way of finding about language", consequently on the process of meaningmaking. This raises a third issue focused on the difference between the modernist and the postmodernist canon: while modernism tried to build different hypotheses using

lexical cohesion, contributes to an understanding of linguistic and cultural mappings at the core of fictional characters' everyday interactions which might be extended to Ireland and its dialectical position in the British Isles, in the United Kingdom (i.e., The United Kingdom of Great Britain and Northern Ireland), and the outer world. both multiple and specific types of language to suggest and explain the multiple flights of creative endeavour, postmodernism resorts most frequently to non-selective description and enumeration, among other, even refusing distinctions. Hamilton recognises this when in an interview he states about his novel that confusion was the best word to describe his childhood'. In his search for an understanding of reality, there is an ongoing display of binaries, very often turning the familiar into unfamiliar and vice versa, exerting a unique impact on readers' interaction with the protagonist's multiple flights of imagination.

\section{Final considerations}

This analysis has benefited from a multilayered interpretive framework drawing on discourse analysis coupled by a corpusbased approach, particularly in that it unpacks ways in which writers make use of linguistic and structures. More than a linguistic choice, shifting focalisations comprise stylistic choices which, in the process, make the reader reflect on "viewpoint, focus and base (i.e., space connectors)", (Sweetser and Fauconnier, 1996, pp. 1-28) on cultural mappings and text worlds. Hence, corpus analysis, now in use in many pedagogical settings as well as research settings, offers students/citizens other ways to meet individuals' needs who, in the long run, so asserts Ogle (2002, p.7), "can use reading to help answer profound questions about themselves and the world" mostly implicit in their interaction with language and literature as textual practices. With regard to the consequences of the current research study, this paper offers a set of observations that can be seen as a way of opening a dialogue between linguistics and literature around issues of linguistic marks in disambiguating speech and through presentation, despite the fact that the survey of the pragma-linguistic structures only draw on a limited corpus of texts. Further studies should involve a larger selection of narrative texts belonging to the modernist and postmodernist period.

${ }^{7}$ Cf. Available at http://cle.ensIyon.fr/anglais/the-speckled-people-aconversation-with-hugo-hamilton197438. kjsp?RH=CDL. 
References

ASAKA, K., 2008. Free indirect discourse and the personal pronoun 'one' in To the Lighthouse. Online Proceedings of the Annual Conference of the Poetics and Linguistics Association (PALA). Available http://www.pala.ac.uk/resources/proceedings/2008/alexander2008.pdf.

ASAKA, K.,2010. Figuring out 'who tells the story' from the personal pronoun: The use of one in Virginia Woolf's short stories. Proceedings of the Annual Conference of the Poetics and Linguistics Association (PALA). Available at: http://www.pala.ac.uk/resources/proceedings/2010/alalami2010.pdf BAKER, P., 2006. Using corpora in discourse analysis. New York: Continuum. BAKHTIN, M. M., 1981. The dialogic imagination: Four essays. M. Holquist, ed. Trans. C. Emerson and M. Holquist, Austin and London: University of Texas Press, (1930; 1975).

BELSEY, C., 2002. Critical practice. London: Methuen.

BHABHA, H. 1998. Culture's in between. In: D. Bennett,ed. Multicultural states: Rethinking difference and identity. London: Routledge, pp. 29-47.

BIBER, D., CONRAD, S. and LEECH G., 2002. Longman student grammar of spoken and written English. Longman: Harlow.

BIBER, D., CONRAD, S. and REPPEN, R., 1998. Corpus linguistics: investigating Language

structure and use. Cambridge: Cambridge University Press.

British National Corpus. Available at: http://www.natcorp.ox.ac.uk/.

BROWN, L. ed.,1 1993. The New Shorter Oxford English Dictionary. Oxford: OUP.

CARTER, R. and MCCARTHY, M., 2006. Cambridge grammar of spoken and written English and usage. Cambridge: CUP.

CAUGHIE, P., 1991. Virginia Woolf and postmodernism: literature in quest \& question of itself. Urbana: University of Illinois Press.

DAICHES, D., 1942. Virginia Woolf. New York: New Directions Books.

DAVID, H., 1994. Textual 'you' and double deixis in Edna O'Brien's A Pagan Place. Style, vol.28, no.3, pp. 378- 411. Available at: http://cogweb.ucla.edu/Abstracts/Herman_94.html

DUPLEISS, R., 1985. "I' rejected; 'we' substituted": The later novels of Woolf. In: Writing beyond the ending: Narrative strategies of twentieth-century women writers. Bloomington: Indian University Press, pp. 162-177.

FLUDERNIK, M., 1993. The fictions of language and the languages of fiction: The linguistic representation of speech and consciousness. London: Routledge.

GENETTE, G., 1988. Narrative discourse. Trans. J. Lewin. Ithaca: Cornell UP.

HAMILTON, H., 2003. The Speckled People: A Memoir of a Half-Irish Childhood Hammersmith: Harper Perennial.

HOEY, M., 1991. Patterns of lexis in text. Oxford: Oxford University Press.

HOEY, M., 2001. Textual interaction: An introduction to written discourse analysis. London: Routledge.

HOEY, M., 2005. Lexical priming: A new theory of words and language. London: Routledge.

HUTCHEON, L., 1984. The theme of linguistic identity: La Macchina Mondiale. In: Narcissistic narrative: The metafictional paradox. London: Routledge, pp. 104-117.

LAKOFF, G., 1996. Sorry, I'm Not Myself Today: The Metaphor System for Conceptualizing the Self. In: G. Fauconnier and E. Sweetser, eds. Spaces, worlds and grammar. Chicago: The University of Chicago Press, pp. 91-123.

MACLEOD, N., 2005. Stylistics and point of view in fiction: A credo and some examples. The European English Messenger. ESSE, vol. 14, no,2, pp. 61-73.

MACOVSKI, M., 1994. Dialogue and literature: Apostrophe, auditors and the collapse of Romantic discourse. Oxford: Oxford University Press.

MARTINEZ, M. A., 2008. Focaliser's inner speech: Levels of participant representation in fictional narrative discourse. Online Paper Abstracts of the Annual Conference of the Poetics and Linguistics Association 2008 (PALA).

MCINTYRE, D., BELLARD-THOMSON, C., HEYWOOD, J., MCENERY, A. M., SEMINO, E. and SHORT, M. H., 2004. Investigating the presentation of speech, writing and thought in British English: A corpus-based approach. ICAME Journal, vol.28, pp. 49-76.

MAHLBERG, M., 2007. Corpus stylistics: bridging the gap between linguistic and literary studies. In: M. Hoey, M. Mahlberg, M. Stubbs and W. Teubert, eds. Text, discourse and corpora. London: Continuum, pp. 219-246. 
NASU, M., 2010. Can we appreciate her 'Moments of Being'? - A stylistic analysis of Woolf's short fiction. Online Proceedings of the Annual Conference of the Poetics and Linguistics Association $\quad$ (PALA). Available
http://www.pala.ac.uk/resources/proceedings/2010/alalami2010.pdf OGLE, D., 2002. Raising reading in the middle. Reading Today, vol. 19, no.4, p. 7. PARTINGTON, A., 1998. Patterns and meanings: Using corpora for English language research and teaching. Philadelphia: John Benjamins.

ROBERT, H., 1954. Stream of consciousness in the modern novel: A study of James Joyce, Virginia Woolf, Dorothy Richardson, William Faulkner and others. Berkeley: University of California Press.

SAMPSON, G. and MCCARTHY, D. eds., 2004. Corpus linguistics: Readings in a widening discipline. London: Continuum.

SEMINO, E. and SHORT, M., 2004. Corpus stylistics: Speech, writing, and thought presentation in a corpus of English writing. London: Routledge.

SEMINO, E., SHORT, M. and CULPEPER, J., 1997. Using a corpus to test and refine a model of speech and thought presentation. Poetics, vol.25, no.1, pp. 17-43. Available at: http://dx.doi.org/10.1016/S0304-422X(97)00007-7.

SIMPSON, P., 1997. Language through literature: An introduction. London: Routledge.

SINCLAIR, J. ed., 1990. Collins Cobuild English grammar. London/Glasgow: Collins.

SINCLAIR, J., 2004. Developing linguistic corpora: A guide to good practice. Ahds literature, languages and linguistics. Available at: www.ahds.ac.uk/creating/guides/linguisticcorpora/chapter1.htm\#section 11 [Accessed 1 February 2006].

SOTIROVA, V., 2009. The roots or routes of a literary style? Joyce's presentation of consciousness in Ulysses. PALA 2009 Abstracts (p. 48). Available at: http://www.roac.nl/roac/_files/conferences/PALA\%202009\%20Book\%20of\%20Abstracts.pdf SOUSA, A., 2008. Mapping out real and imaginary settings: Cohesion in Hamilton's The Speckled People. Dedalus 11-12 - A llha e os Mapas da Cultura, pp.195-224.

STANZEL, F. K., 1988. A theory of narrative. Cambridge: CUP.

STOCKWELL, P., 2002. Miltonic texture and the feeling of reading. In E. Semino and J. Culpeper, eds. Cognitive stylistics. language and cognition in text analysis. Amsterdam/Philadelphia: John Benjamins. pp. 73-94.

SWEETSER, E. and FAUCONNIER, G., 1996. Cognitive links and domains. In: G. Fauconnier and E. Sweetser, eds. Spaces, worlds and grammar. Chicago: The University of Chicago Press, pp. 1-28.

TRENGOVE, G., 1975. Who is you? Grammar in Grassic Gibbon. Scottish Literary Journal, vol.2, no.2, pp. 47-62.

QUIRK, R. and GREENBAUM, S., 1993. A university grammar of English. Hong Kong: Longman.

WALES, K. 1997. Dictionary of stylistics. London and New York: Longman.

WIDDOWSON, H. 1975. Stylistics and the teaching of literature [1991]. London: Longman.

WOOLF, V., 1982. Night and Day. London: Granada (1919).

WOOLF, V., 2002. Between the Acts. The Shakespeare Head Press Edition. Oxford: Blackwell (1941).

WYNNE, M., SHORT, M. and SEMINO, E., 1998. A corpus-based investigation of speech, thought and writing presentation in English narrative texts. In: A. Renouf, ed. Explorations in corpus linguistics. Amsterdam: Rodopi, pp. 233-250.

WYNNE, M., 2006. Stylistics. Corpus approaches. In: K. Brown, ed. Encyclopedia of language and linguistics. Oxford: Elsevier, pp. 223-226. 
Author's address and contact details

Alcina Maria Pereira de Sousa

University of Madeira

ULICES, University of Lisbon

Alameda da Universidade, 1600-214 Lisboa

Portugal

Phone: +351217920092

E-mail: ninita@uma.pt

Alda Maria Correia

New University

ULICES, University of Lisbon

Alameda da Universidade, 1600-214 Lisboa

Portugal

Phone: +351217920092

E-mail: camj@fcsh.unl.pt 